JPdK Volume 2 No1 Tahun 2020 Halaman 42-46

JURNAL PENDIDIKAN dan KONSELING

UNIVERSITAS

Research \& Learning in Primary Education

\title{
Efektivitas Media Pembelajaran Cerita Bergambar Atau Komik Bagi Siswa Sekolah Dasar
}

\author{
Syera Trivena Dessiane ${ }^{1}$, Nyoto Hardjono ${ }^{2}$ \\ Program Studi Pendidikan Guru Sekolah Dasar \\ Fakultas Keguruan dan Ilmu Pendidikan \\ Universitas Kristen Satya Wacana \\ Email:292017044@student.uksw.edu
}

\begin{abstract}
Abstrak
Penelitian ini bertujuan untuk mengetahui perbedaan efektivitas metode pembelajaran lain dengan metode pembelajaran menggunakan media cerita bergambar bagi siswa di sekolah dasar. Jenis penelitian yang digunakan adalah meta analisis dari penelitian yang telah dilakukan sebelumnya. Penelitian ini menggunakan metode kualitatif. Tujuan dari penelitian ini adalah untuk mengetahui efektivitas media pembelajaran cerita bergambar bagi siswa sekolah dasar. Pengumpulan data dalam penelitian ini dilakukan dengan menelusuri jurnal melalui Google Cendekia. Kata kunci yang digunakan untuk penelusuran jurnal adalah: efektifitas, media cerita bergambar, komik, siswa SD. Hasil analisis menunjukan bahwa penggunaan media cerita bergambar atau komik untuk siswa sekolah dasar terjadi peningkatan respon siswa mulai dari yang terendah $4,27 \%$ hingga yang tertinggi $138,76 \%$ dengan rata-rata sebesar $43,50 \%$.
\end{abstract}

Kata kunci: Efektivitas, cerita bergambar, komik, siswa SD.

\begin{abstract}
This study aims to determine the differences in the effectiveness of other learning methods with learning methods using pictorial story media for students in primary schools. This type of research is a meta-analysis of research that has been done before. This study uses a qualitative method. The purpose of this study was to determine the effectiveness of pictorial story learning media for elementary school students. Data collection in this research was carried out by searching journals through Google Scholar. The keywords used for journal search are: effectiveness, pictorial story media, comics, elementary studentsThe analysis showed that the use of pictorial or comic story media for elementary school students increased student responses starting from the lowest $4.27 \%$ to the highest $138.76 \%$ with an average of $43.50 \%$.
\end{abstract}

Keywords: Effectiveness, pictorial story media, comics, elementary students.

\section{PENDAHULUAN}

Pembelajaran yang efektif tidak cukup jika hanya memberikan informasi saja, karena siswa SD memiliki sifat mudah jenuh sehingga untuk mengajak siswa belajar biasanya guru menggunakan alat peraga untuk memancing minat belajar siswa. Alat peraga yang dimaksud dapat berupa penggunaan media pembelajaran. Hal ini bertujuan untuk memberikan informasi sekaligus pengalaman bagi siswa.

Menurut Oemar Hamalik, media pembelajaran adalah alat, metode, dan teknik yang digunakan dalam rangka lebih mengefektifkan komunikasi dan interaksi antara guru dan siswa dalam proses pendidikan dan pengajaran di sekolah. Sedangkan Menurut Suprapto dkk, menyatakan bahwa media pembelajaran adalah suatu alat pembantu secara efektif yang dapat digunakan oleh guru untuk mencapai tujuan yang diinginkan. Dari kedua pendapat tersebut dapat disimpulkan bahwa media pembelajaran adalah alat yang digunakan untuk mengefektifkan pembelajaran untuk mencapai tujuan yang diinginkan. 
Untuk menjadikan sebuah pembelajaran yang efektif, diperlukan media pembelajaran yang dapat membantu tercapainya tujuan pembelajaran. pemilihan media pembelajaran juga seharusnya disesuaikan dengan kemampuan dan karakteristik siswa. Penggunaan media pembelajaran ceria bergambar atau komik bagi siswa SD bisa dijadikan pilihan. Cerita bergambar atau komik adalah media pembelajaran yang cukup menarik karena memuat gambar dan kata-kata, dimana gambar dan kata-kata membentuk kesatuan yang utuh menjadi sebuah cerita yang dapat menarik perhatian siswa. Media pembelajaran berupa cerita bergambar atau komik memiliki karakteristik penyampaian pesan yang sederhana, jelas, dan mudah untuk dipahami siswa SD. Siswa SD akan lebih senang membaca materi yang berupa gambar yang penuh warna dibandingkan dengan hanya membaca sebuah teks panjang. Melalui penggunaan media pembelajaran berupa media cerita bergambar atau komik diharapkan mampu mempertinggi kualitas belajar mengajar siswa SD.

\section{METODOLOGI PENELITIAN}

Penelitian ini menggunakan data dokumen atau hasil penelitian yang sudah

Tabel 1. Besarnya Peningkatan Hasil dari Penggunaan Cerita Bergambar atau Komik sebagai Media Pembelajaran bagi Siswa Sekolah Dasar

\begin{tabular}{|c|c|c|c|c|c|c|}
\hline \multirow{2}{*}{ No. } & \multirow{2}{*}{ Judul } & \multirow{2}{*}{ Peneliti } & \multicolumn{4}{|c|}{ Peningkatan hasil } \\
\hline & & & Semula & Sesudah & Gain & $\operatorname{Gain}(\%)$ \\
\hline \multirow[t]{8}{*}{1} & Efektifitas & Putri S, Sri H. & 53,85 & 78,88 & 25,03 & 46,48 \\
\hline & Penggunaan & & & & & \\
\hline & Papan & & & & & \\
\hline & Bergambar & & & & & \\
\hline & Pembelajaran & & & & & \\
\hline & Berbicara Di Kelas II & & & & & \\
\hline & Mojowuku & & & & & \\
\hline & Kedamean Gresik & & & & & \\
\hline \multirow[t]{9}{*}{2} & Efektivitas & Nur F, Sri H. & 55,92 & 81,53 & 25,61 & 45,80 \\
\hline & Penggunaan & & & & & \\
\hline & Komik Buta Dalam & & & & & \\
\hline & Pembelajaran & & & & & \\
\hline & Menulis & & & & & \\
\hline & Cerita Siswa Kelas & & & & & \\
\hline & IV SDN Watudakon & & & & & \\
\hline & Kesamben & & & & & \\
\hline & Jombang & & & & & \\
\hline \multirow[t]{4}{*}{3} & Efektivitas & Doni, O & 53,23 & 72,79 & 19,56 & 36,75 \\
\hline & Penggunaan & & & & & \\
\hline & Terhadap & & & & & \\
\hline & Hasil Belajar Siswa & & & & & \\
\hline
\end{tabular}

dilakukan. Pengumpulan data dilakukan dengan menelusuri melalu Google Cendekia. Kata kunci yang digunakan saat penelusuran jurnal adalah: efektivitas, cerita bergambar, komik, siswa SD. Dari hasil penelusuran, diperoleh beberapa jurnal dan dipilih yang memenuhi kriteria. Dari cerita bergambar dan komik, dipilih 10 hasil penelitian untuk dianalisis lebih lanjut. Analisis dilakukan dengan membandingkan selisih skor nilai sebelum penggunaan media cerita bergambar atau komik dengan.

\section{HASIL PENELITIAN DAN PEMBAHASAN}

Setelah melakukan penelusuran di Google Cendekia menggunakan kata kunci: efektivitas, cerita bergambar, komik, siswa SD, dipilih 10 penelitian antara lain: Doni O. (2014), Nova T. (2018), Anggit G, Oka I, \& Jumanto. (2017),Afif H. (2013), Hadi W, Rahmi S, \& Sri S(2015), Putri S, Sri H. (2015), Nur F, Sri H. (2017), Nur K.(2017), Fitri A. (2012), Jufri A, Wahyu S. (2013).

Hasil analisis terkait efektivitas media pembelajaran cerita bergambar atau komik bagi siswa sekolah dasar adalah sebagai berikut 


\begin{tabular}{|c|c|c|c|c|c|c|}
\hline \multirow{2}{*}{ No. } & \multirow{2}{*}{ Judul } & \multirow{2}{*}{ Peneliti } & \multicolumn{4}{|c|}{ Peningkatan hasil } \\
\hline & & & Semula & Sesudah & Gain & $\operatorname{Gain}(\%)$ \\
\hline \multirow{11}{*}{4} & Pada Mata Pelajaran & & & & & \\
\hline & Ips Kelas 5 SD & & & & & \\
\hline & Negeri 1 Kayen & & & & & \\
\hline & Tahun Pelajaran & & & & & \\
\hline & $2013-2014$ & & & & & \\
\hline & Pengembangan Buku & Nova $T$. & 64,89 & 88,53 & 23,64 & 36,43 \\
\hline & Cerita Bergambar & & & & & \\
\hline & Untuk Meningkatkan & & & & & \\
\hline & Minat Baca Siswa & & & & & \\
\hline & Kelas IV Sekolah & & & & & \\
\hline & Dasar & & & & & \\
\hline \multirow[t]{6}{*}{5} & Efektifitas & Anggit G, Oka I, & 43,33 & 71,00 & 27,67 & 63,86 \\
\hline & Penggunaan Media & \& Jumanto. & & & & \\
\hline & Komik Komsa & & & & & \\
\hline & Berbasis Kontekstual & & & & & \\
\hline & Dalam Pembelajaran & & & & & \\
\hline & Sains Di SD & & & & & \\
\hline \multirow[t]{8}{*}{6} & Efektivitas & Afif $\mathrm{H}$. & 7,85 & 9,15 & 1,3 & 16,56 \\
\hline & Cerita Bergambar & & & & & \\
\hline & Dan Ular Tangga & & & & & \\
\hline & Dalam Pendidikan & & & & & \\
\hline & Kesehatan Gigi Dan & & & & & \\
\hline & Mulut Siswa SDN 2 & & & & & \\
\hline & Patrang Kabupaten & & & & & \\
\hline & Jember & & & & & \\
\hline \multirow[t]{8}{*}{7} & Efektivitas & Hadi W, Rahmi S, & 35,37 & 36,88 & 1,51 & 4,27 \\
\hline & Komik Mengenai & $\&$ Sri S & & & & \\
\hline & Jajanan Yang Aman & & & & & \\
\hline & Terhadap & & & & & \\
\hline & Pengetahuan & & & & & \\
\hline & Sikap Siswa Di SDN & & & & & \\
\hline & 032 Samarinda Utara & & & & & \\
\hline & Tahun 2015 & & & & & \\
\hline \multirow[t]{6}{*}{8} & Penggunaan Media & Nur K & 64,81 & 87,41 & 22,6 & 34,87 \\
\hline & Cerita Bergambar & & & & & \\
\hline & Untuk Meningkatkan & & & & & \\
\hline & Kemampuan Menulis & & & & & \\
\hline & Puisi Siswa Kelas V & & & & & \\
\hline & Sekolah Dasar & & & & & \\
\hline \multirow[t]{7}{*}{9} & Pengaruh & Fitri A & 31,71 & 75,71 & 44 & 138,76 \\
\hline & Pemanfaatan Media & & & & & \\
\hline & Komik Matematika & & & & & \\
\hline & Terhadap & & & & & \\
\hline & Belajar Kelas V SDN & & & & & \\
\hline & Pontiana & & & & & \\
\hline & Tenggara & & & & & \\
\hline \multirow[t]{7}{*}{10} & Penggunaan & Jufri A, Wahyu S & 72,1 & 80,2 & 8,1 & 11,23 \\
\hline & Komik & & & & & \\
\hline & Meningkatkan & & & & & \\
\hline & Keterampilan & & & & & \\
\hline & Membaca Cerita Di & & & & & \\
\hline & Kelas V Sekolah & & & & & \\
\hline & Dasar & & & & & \\
\hline
\end{tabular}




\begin{tabular}{|c|c|c|c|c|c|c|c|c|c|}
\hline & & & Pai & ed Samples & Test & & & & \\
\hline & & & Pai & ed Differen & & & & & \\
\hline & & & Std. & Std. Error & $\begin{array}{r}95 \% \mathrm{Co} \\
\text { Interva } \\
\text { Diffe }\end{array}$ & $\begin{array}{l}\text { fidence } \\
\text { of the } \\
\text { ence }\end{array}$ & & & $\begin{array}{l}\text { Sig. } \\
(2-\end{array}$ \\
\hline & & Mean & Deviation & Mean & Lower & Upper & $\mathrm{t}$ & df & tailed) \\
\hline $\begin{array}{l}\text { Pair } \\
1\end{array}$ & $\begin{array}{l}\text { sebelum - } \\
\text { sesudah }\end{array}$ & $-19,90200$ & 13,10169 & 4,14312 & $-29,27439$ & $-10,52961$ & $-4,804$ & 9 & ,001 \\
\hline & & & & & & & \begin{tabular}{l|r} 
& Corr \\
$\mathrm{N}$ & $\mathrm{O}$ \\
\end{tabular} & $\begin{array}{l}\text { elati } \\
\text { n }\end{array}$ & Sig. \\
\hline & & & & & $\begin{array}{ll}\text { air } & \text { sebelu } \\
& \text { sesud }\end{array}$ & & 10 & ,862 &, 001 \\
\hline & & & & & Sesu & $\mathrm{Ga}$ & & $\operatorname{Gain}(c$ & \\
\hline Rat & Rata & & & 48,3 & 68,21 & 19,90 & & 3,50 & \\
\hline
\end{tabular}

Dari data pada Tabel 1. tersebut dapat dilihat bahwa media pembelajaran cerita bergambar atau komik efektif untuk diterapkan bagi pembelajaran siswa sekolah dasar. Peningkatan respyh siswa mulai Penelityang terendah $4,27 \%$ hingga yang tertinggi 138,76 $\%$ dengan rata-rata sebesar $43,50 \%$. Efektivitas pembelajaran sebelum menggunakan media cerita bergambar atau komik dan sesudah menggunakan media cerita bergambar atau komik mengalami peningkatan yang cukup baik yaitu $43,50 \%$.

Tabel 2. Tabel Paired Samples Statistic Paired Samples Statistics

\begin{tabular}{lll|c|c|c} 
& & & $\begin{array}{c}\text { Std. } \\
\text { Deviatio } \\
\text { n }\end{array}$ & $\begin{array}{l}\text { Std. } \\
\text { Error } \\
\text { Mean }\end{array}$ \\
\hline $\begin{array}{l}\text { Pair } \\
1\end{array}$ & $\begin{array}{l}\text { sebelu } \\
\text { m }\end{array}$ & 48,3060 & 10 & 19,23751 & 6,08343 \\
\cline { 2 - 5 } & sesudah & 68,2080 & 10 & 25,32289 & 8,00780 \\
\hline
\end{tabular}

\section{Tabel 4. Tabel Paired Samples Test}

Model pembelajaran dengan cerita bergambar atau komik digunakan oleh para guru sebagai dasar melaksanakan kegiatan pembelajaran dengan baik, dan sebagai suatu alternatif dalam usaha meningkatkan hasil belajar peserta didik. Dalam pembelajaran yang menerapkan model berbantuan cerit bergambar atau komik siswa mengalami pembelajaran yang bermakna.

Berdasarkan analisis beberapa hasil penelitian tentang penggunaan dan efektivitas media cerita bergambar atau komik bagi siswa sekolah dasar, dapat ditarik kesimpulan bahwa penggunaan media pembelajaran cerita
Berdasarkan Tabel 2. menunjukan bahwa penggunaan media cerita bergambar atau komik efektif digunakan dengan nilai rata-rata 48,30 menjadi 68,20.

Tabel 3. Tabel Paired Samples Corelations

Berdasarkan Tabel 3. menunjukan adanya korelasi penggunaan media cerita bergambar atau komik dengan efektivitas pembelajaran sebesar 0,862 .Selanjutnya pada Tabel 4. tampak bahwa nilai Sig.(2-tailed) $(0,001)<\propto(0,05)$ dan $t_{\text {hitung }}=-4,804<\mathrm{t}_{\text {tabel }}=$ 2,262 sehingga $\mathrm{H}_{0}$ ditolak. Jadi dapat disimpulkan bahwa ada perbedaan rata-rata hasil sebelum menggunakan media cerita bergambar atau komik dan sesudah menggunakan media cerita bergambar atau komik.

bergambar atau komik efektif untuk diterapkan untuk pembelajaran bagi siswa sekolah dasar.

\section{SIMPULAN}

Berdasarkan hasil analisis penelitian penggunaan media cerita bergambar atau komik untuk siswa sekolah dasar, dapat disimpulkan bahwa penggunaan media cerita bergambar atau komik untuk siswa sekolah dasar terjadi peningkatan respon siswa mulai dari yang terendah $4,27 \%$ hingga yang tertinggi $138,76 \%$ dengan rata-rata sebesar $43,50 \%$. Saran bagi penelitian selanjutnya ialah menggunakan lebih banyak jurnal, 
artikel, dan sumber lain yang relevan. Peneliti hendaknya mampu memilih hasil penelitian dengan baik agar dalam penelian meta-analisis hasil yang diperoleh lebih akurat

\section{DAFTAR PUSTAKA}

Ahmat, J. (2013). Penggunaan media komik untuk meningkatkan keterampilan membaca cerita di kelas V Sekolah Dasar. Jurnal Penelitian Pendidikan Guru Sekolah Dasar, 1(2), 19.https://jurnalmahasiswa.unesa.ac.id/in dex.php/jurnal-penelitianpgsd/article/view/3025

Apriyanti, F., \& Margiati, K. Y. (2012). Pengaruh pemanfaatan media komik matematika terhadap hasil belajar kelas $V$ SDN 24 pontianak tenggara. Jurnal Pendidikan dan Pembelajaran Khatulistiwa,

1(1).http://jurnal.untan.ac.id/index.php/j $\mathrm{pdpb} /$ article/view/450

Arsyad, A. (2011). Media pembelajaran.

Fitri Widya Ningrum, N. (2017). Efektivitas Penggunaan Media Komik Buta dalam Pembelajaran Menulis Dialog Cerita Siswa Kelas IV Sdn Watudakon I Kesamben Jombang. Jurnal Penelitian Pendidikan Guru Sekolah Dasar, 5(3).https://jurnalmahasiswa.unesa.ac.id /index.php/jurnal-penelitianpgsd/article/view/20023

Hamalik, Oemar. 1989. Media Pendidikan. Bandung : Citra Aditya.

Hamdalah, A. (2013). Efektivitas media cerita bergambar dan ular tangga dalam pendidikan kesehatan gigi dan mulut siswa SDN 2 Patrang Kabupaten Jember. Journal Promkes, 1, 118-123.

Khamidah, N. (2017). Penggunaan Media Cerita Bergambar Untuk Meningkatkan Kemampuan Menulis Puisi Siswa Kelas $V$ Sekolah Dasar. ELSE (Elementary School Education Journal): Jurnal Pendidikan dan Pembelajaran Sekolah Dasar,

1(2b).http://103.114.35.30/index.php/pg sd/article/view/1059

SETYAWARDANA, D. O. (2014). Efektivitas Penggunaan Media Komik Terhadap Hasil Belajar Siswa Pada Mata Pelajaran Ips Kelas 5 Sd Negeri 1 Kayen Tahun Pelajaran 2013-2014 (Doctoral dissertation, Universitas
Muhammadiyah

Surakarta).http://eprints.ums.ac.id/2876 4/

Shalahiddin, Mahfud. 1986. Media Pendidikan Agama. Bandung : Bina Islam.

Sinta, P. (2016). Efektifitas Penggunaan Media Papan Cerita Bergambar dalam Pembelajaran Berbicara di Kelas II Sdn Mojowuku Kedamean Gresik. Jurnal Penelitian Pendidikan Guru Sekolah Dasar,

3(2).https://jurnalmahasiswa.unesa.ac.id /index.php/jurnal-penelitianpgsd/article/view/15524

Tarigan, N. T. (2019). Pengembangan Buku Cerita Bergambar Untuk Meningkatkan Minat Baca Siswa Kelas IV Sekolah Dasar. Jurnal Curere, 2(2).http://www.portaluniversitasquality .ac.id:5388/ojssystem/index.php/CURE $\mathrm{RE} /$ article/view/157

Wicaksono, A. G., Irmade, O., \& Jumanto, J. (2018, February). EFEKTIFITAS PENGGUNAAN MEDIA KOMIK KOMSA BERBASIS KONTEKSTUAL DALAM PEMBELAJARAN SAINS DI $S D$. In Seminar Nasional Pendidikan IPA 2017 (Vol.

2).http://pasca.um.ac.id/conferences/ind ex.php/ipa2017/article/view/1125

Wijaya, H., Susanti, R., \& Sunarti, S. (2015). Efektivitas Media Komik Mengenai Jajanan yang Aman terhadap Pengetahuan dan Sikap Siswa di SDN 032 Samarinda Utara Tahun 2015.https://dspace.umkt.ac.id/handle/4 $63.2017 / 486$ 